\title{
ANALISIS STRUKTUR, PERILAKU DAN KINERJA PASAR INDUSTRI TUNA DI INDONESIA
}

\section{Structure, Conduct and Performance Analysis of Tuna Industries in Indonesia}

\author{
*Freshty Yulia Arthatiani, Estu Sri Luhur, Siti Hajar Suryawati dan Tikkyrino Kurniawan \\ Balai Besar Riset Sosial Ekonomi Kelautan dan Perikanan \\ Gedung BRSDM KP I Lt. 4 \\ Jalan Pasir Putih Nomor 1 Ancol Timur, Jakarta Utara, Indonesia \\ Telp: (021) 64711583 Fax: 64700924
}

Diterima tanggal: 27 November 2019; Diterima setelah perbaikan: 11 Mei 2020;

Disetujui terbit: 30 Juni 2020

\begin{abstract}
ABSTRAK
Tuna merupakan komoditas ekspor perikanan utama di Indonesia. Berdasarkan data Badan Pusat Statistik (BPS) ekspor tuna Indonesia mengalami tren pertumbuhan nilai ekspor yang melambat dari tahun 2012 hingga 2018. Oleh karena itu perlu dilakukan analisis mengenai struktur perilaku dan kinerja pemasaran industri tuna di Indonesia yang diharapkan dapat mendukung kinerja ekspor tuna Indonesia. Penelitian ini menggunakan data sekunder dari Kementerian Kelautan dan Perikanan dan BPS serta data primer bersumber dari pelaku usaha tuna. Metode penelitian yang digunakan adalah analisis struktur pasar dengan perhitungan konsentrasi pasar dan hambatan masuk pasar, serta perilaku pasar yang dianalisis secara deskriptif selain itu kinerja pasar dianalisis menggunakan perhitungan variabel price cost margin (PCM) dan efisiensi internal (Xeff). Hasil analisis struktur pasar menunjukkan bahwa komoditas tuna memiliki struktur pasar oligopoli, meskipun untuk komoditas tuna olahan dapat dikategorikan oligopoli ketat cenderung monopoli. Analisis perilaku pasar menunjukkan bahwa penentuan harga tuna ekspor dilakukan oleh buyer dan promosi dilakukan melalui ajang pameran perdagangan serta pengiriman sampel kepada calon buyer. Perhitungan indikator kinerja pasar menunjukkan bahwa kinerja pemasaran tuna beku lebih baik dibandingkan tuna olahan. Rekomendasi kebijakan yang disarankan adalah dengan kebijakan mempermudah investasi sehingga meningkatkan jumlah pelaku usaha dan menurunkan tingkat persaingan. Selain itu perlu pengawasan oleh komite persaingan usaha terutama pada komoditas tuna olahan untuk menghindari kecenderungan monopoli bahan baku. Peningkatan daya saing dari tuna Indonesia perlu juga dilakukan agar lebih berperan dalam menentukan harga di pasar ekspor. Kinerja pasar dapat ditingkatkan melalui penghematan biaya input atau peningkatan volume output untuk meningkatkan nilai efisiensi internal.
\end{abstract}

Kata Kunci: struktur; perilaku; kinerja; tuna; pemasaran

\section{ABSTRACT}

Tuna is a major fishery export commodity in Indonesia, although based on data from the Central Bureau Statistics Indonesian tuna exports experience a slowing trend in the value of exports from 2012 to 2018. Therefore it is necessary to analyze the structure, conduct and performance from of the tuna industry. This study uses secondary data from the Ministry of Maritime Affairs and Fisheries and Central Bureau of Statistics while primary data sourced from tuna entrepreneurs. The research method used is the analysis of market structure by calculating market concentration and barriers to market entry, as well as market conducts analyzed descriptively. In addition, market performance is analyzed using the calculation of price cost margin (PCM) and internal efficiency (Xeff). The results of the market structure analysis show that tuna has an oligopoly market structure. Analysis of market conduct shows that the determination of the price of export tuna is carried out by the buyer and promotion is carried out through a trade exhibition and sending samples to prospective buyers. The calculation of market performance indicators shows that the marketing performance of frozen tuna is better than processed tuna. The recommended policy are to facilitate investment to reducing the level of competition. In addition it needs supervision by the business competition committee, especially on processed tuna commodities. Increasing the competitiveness of Indonesian tuna also needs to be done to be more instrumental in determining prices in the export market. Market performance can be improved through saving input costs or increasing output volume.

Keywords: shrimp; market structure; market behavior; market performance 


\section{PENDAHULUAN}

Indonesia merupakan produsen perikanan tangkap kedua terbesar di dunia dengan rata-rata produksi dari tahun 2005-2014 mencapai 5.074.932 ton/tahun (FAO, 2018). Selain itu Indonesia juga merupakan produsen perikanan budi daya dan perairan umum salah satu yang terbesar di dunia, sehingga menempatkan Indonesia sebagai produsen perikanan utama di dunia bersama dengan China, USA, Russia dan Jepang. Potensi dan produksi ikan yang melimpah di Indonesia menjadikan negara ini merupakan salah satu negara pengekspor utama komoditas perikanan dengan nilai ekspor pada tahun 2018 mencapai USD 5.596.086.290 dengan volume ekspor mencapai 1.975.824.633 kg (BPS, 2018).

Ekspor perikanan terdiri dari beberapa komoditas utama yang dominan menyumbang nilai ekspor terbesar salah satunya adalah ekspor tuna. Nilai ekspor tuna menyumbang rata-rata $14 \%$ dari total nilai ekspor perikanan sehingga berperan dalam menyumbang devisa bagi perekonomian nasional yang masih potensial untuk terus ditingkatkan. Peningkatan ekspor tuna dapat disebabkan karena konsumsi ikan dunia yang terus mengalami peningkatan setiap tahunnya, data FAO (2018) menunjukkan bahwa peningkatan supply ikan untuk kebutuhan konsumsi manusia mengalami pertumbuhan rata-rata 3,2\% per tahun dari tahun 1961-2016. Konsumsi ikan dunia memiliki kecenderungan terus meningkat dimana didalamnya juga termasuk konsumsi tuna menyebabkan peluang peningkatan ekspor tuna masih terbuka lebar. Permintaan ikan tuna dunia terus mengalami peningkatan yang digerakkan oleh peningkatan permintaan untuk produk tuna kaleng dan tuna untuk sushi dan sashimi terutama pada pasar-pasar non tradisional seperti Asia Timur, China, Asia Selatan dan Amerika Latin (FAO, 2016), akan tetapi pertumbuhan ekspor tuna Indonesia cenderung melambat yang ditunjukkan pada Gambar 1.

Gambar 1 menunjukkan bahwa pertumbuhan nilai ekspor tuna dari tahun 2012-2018 secara rata-rata hanya sebesar $1 \%$ yang disebabkan adanya penurunan ekspor dari tahun 2013 sampai dengan 2016. Penelitian Macfadyen, Huntington, Caillart \& Defaux (2016) menunjukkan bahwa Indonesia merupakan negara utama penghasil tuna di dunia pada tahun 2014 dengan total produksi mencapai 653.404 ton namun besarnya produksi ini tidak meningkatkan pertumbuhan ekspor tuna secara signifikan. Hal ini mengindikasikan besarnya potensi sumberdaya ikan yang dimilikioleh Indonesia belum dikelola optimal untuk dapat meningkatkan ekspor tuna nasional. Daya saing tuna pada pasar internasional telah dikaji sebelumnya oleh Cahya (2010) yang menganalisis struktur pasar tuna di pasar internasional dan menganalisis keunggulan komparatif dan keunggulan kompetitif. Akan tetapi penelitian tersebut belum menjelaskan kondisi industri tuna di dalam negeri sehingga belum cukup diperoleh informasi bagaimana kondisi dan persaingan usaha antara pelaku usaha tuna di dalam negeri. Masalah kelangkaan bahan baku menjadi isu utama yang dihadapi oleh pelaku usaha di dalam negeri yang sejatinya telah dirasakan dari sebelum tahun 2000 (Poernomo et al., 2001). Kelangkaan bahan baku ini terjadi karena produksinya yang sangat tergantung musim yang disebabkan karena karakteristik ikan tuna bersifat oseanik atau memiliki sifat selalu beruaya dari suatu perairan ke perairan lainnya sehingga daerah penangkapannya tersebar di seluruh dunia (Sibagariang, Fauziyah \& Agustriarini, 2011). Selain itu kebijakan pemerintah

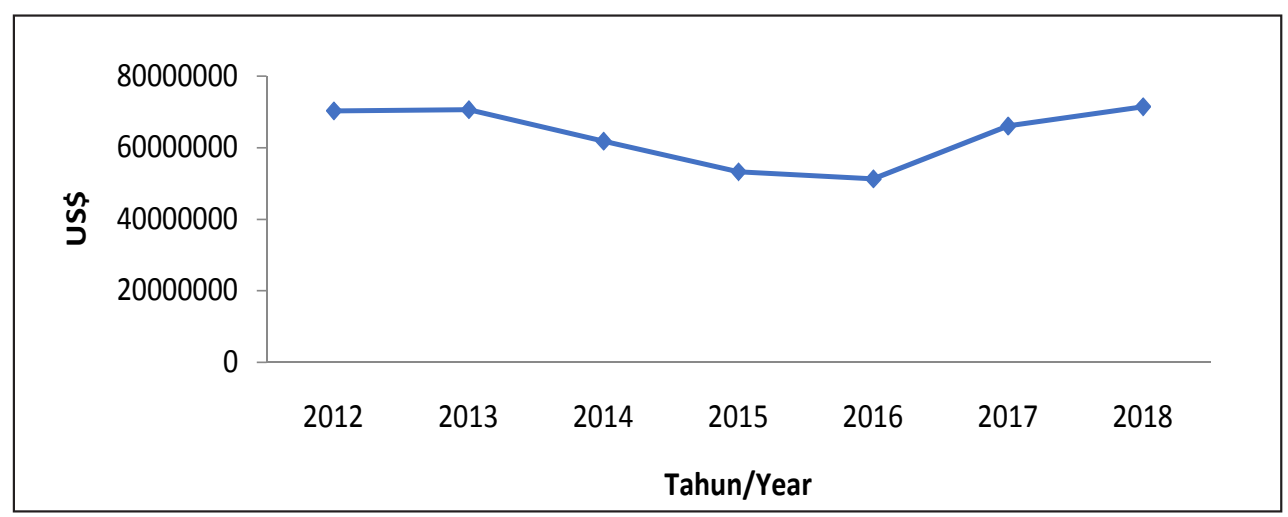

Gambar 1. Ekspor Tuna Indonesia Tahun 2012-2018 (US\$/Tahun). Figure 1. Indonesian Tuna Exports for 2012-2018 (US\$/Year). 
terkait pengelolaan perikanan tangkap diantaranya moratorium kapal transshipment dan kapal eks asing juga menyebabkan terjadinya penurunan produksi tuna dalam negeri sehingga tidak cukup bahan baku untuk ekspor yang ditunjukkan melalui penurunan ekspor tuna di Jawa Timur (Syahrani, Musadieq \& Darmawan, 2017).

Kelangkaan pasokan bahan baku ikan yang dihadapi oleh industri pengolahan ikan dalam negeri saat menyebabkan utilitas unit pengolahan ikan kurang optimal karena kapasitas yang terpasang jauh lebih besar dibandingkan produksi yang dilakukan. Berdasarkan penelitian Poernomo \& Heruwati (2011) pada industri pengalengan tuna dan cakalang hanya terpenuhi $40 \%$ dari kapasitas terpasang karena adanya kelangkaan bahan baku ikan. Hal ini juga dapat menyebabkan persaingan yang tinggi dalam memperoleh bahan baku antar perusahaan sehingga menyebabkan tingginya hambatan masuk pasar yang dapat menyebabkan kinerja pasar menjadi kurang optimal. Kajian terhadap kondisi industri tuna didalam negeri masih perlu untuk dilakukan untuk menggambarkan tingkat persaingan industri di dalam negeri yang pada akhirnya dapat dirumuskan rekomendasi untuk mengoptimalkan kinerja industri tuna dalam negeri. Oleh karena itu penelitian ini bertujuan untuk menganalisis bagaimana struktur perilaku dan kinerja industri tuna Indonesia terutama pada level eksportir tuna Indonesia. Hal ini diharapkan dapat memberikan informasi terkait tingkat persaingan usaha dan perilaku perusahaanan pada industri tuna sehingga mendukung peningkatan ekspor tuna nasional.

\section{METODOLOGI}

\section{Jenis dan Sumber Data}

Data yang digunakan dalam penelitian ini adalah data primer dan data sekunder. Data sekunder berupa data ekspor tuna dari BKIPM, KKP tahun 2017-2018 berdasarkan eksportir dan jenis komoditasnya yakni tuna segar, beku dan olahan untuk menganalisis struktur pasar tuna Indonesia. Analisis perilaku pasar menggunakan data primer yang diperoleh dari FGD dengan 8 perusahaan tuna di Jawa Timur dan 6 perusahaan tuna di DKI Jakarta serta perwakilan dari asosiasi tuna Indonesia serta instansi pemerintah meliputi Kementerian Perdagangan dan Kementerian Kelautan dan Perikanan. Analisis kinerja pemasaran menggunakan data survey Industri Besar Sedang (IBS) dari BPS tahun 2011-2015 yang dipilih berdasarkan Klasifikasi Baku Lapangan Usaha (KBLI) yang diasumsikan dapat mewakili komoditas tuna yang dianalisis dalam penelitian ini yakni kode KBLI 10213 untuk tuna beku dan kode KBLI 10219 untuk tuna olahan.

\section{Ruang Lingkup Penelitian}

Penelitian ini membatasi industri tuna yang dianalisis berdasarkan perusahaan yang melakukan ekspor tuna dan jenis komoditasnya yakni tuna segar, beku dan olahan. Penelitian ini tidak mengkaji industri tuna pada subsektor penangkapan tuna serta belum dapat menganalisis kinerja pemasaran untuk industri tuna segar yang disebabkan belum tersedianya data perusahaan tuna segar pada survey Industri Besar Sedang yang dilakukan oleh BPS.

\section{Waktu dan Lokasi Penelitian}

Waktu penelitian dilakukan dari bulan Oktober hingga Desember 2018 dengan lokasi penelitian di Jawa Timur, Bali dan DKI Jakarta yang mewakili industri tuna di Indonesia.

\section{Metode Analisis Data}

Data yang diperoleh dianalisis secara deskriptif melalui analisis kuantitatif dan analisis kualitatif dengan Structure-Conduct-Performance (SCP) yang merupakan paradigma bahwa kinerja ekonomi dari sebuah industri adalah fungsi dari perilaku penjual dan pembeli yang dihubungkan dengan struktur dalam industri (Bain, 1956 dalam Mcwilliams, 1993). Analisis kuantitatif yang digunakan untuk mengetahui struktur pasar menurt Baye (2010) adalah menggunakan perhitungan Herfindahl-Hirschman Index (HHI), dan Concentration Ratio (CR) untuk mengetahui konsentrasi pasar dengan rumus sebagai berikut:

$$
H H I=S i_{1}{ }^{2}+S i_{2}{ }^{2}+\ldots \ldots .+S i_{n}{ }^{2}
$$

Keterangan/Remarks:

$\mathrm{HHI}=$ Herfindahl-Hirschman Index /HerfindahlHirschman Index

$\mathrm{S}_{i} \quad=$ Pangsa pasar perusahaan (persen) $/$ Market share of firm (percent)

$\mathrm{n} \quad=$ Jumlah total seluruh perusahaan yang berada pada industri/ Total number of all companies in the industry

Herfindahl Hirschman Index sering disebut dengan herfindahl indeks adalah ukuran stastik dari konsentasi pasar dan dapat digunakan dalam 
berbagai macam konteks (Rhoades, 1993). Indeks akan mendekati 0 (nol) ketika terdapat banyak perusahaan dalam satu pasar dengan distribusi yang hampir sama (mendekati pasar persaingan sempurna) dan mendekati 10.000 ketika terjadi monopoli. Pada indeks ini terdapat karakteristik pada bobot, yang dibebankan relatif pada pangsa pasar perusahaan besar dibandingkan dengan pangsa pasar perusahaan kecil (Juwita, 2004). Secara umum, Komisi Pengawas Persaingan usaha (KPPU) membagi tingkat konsentrasi pasar ke dalam dua spektrum berdasarkan nilai HHI, yaitu spektrum I (konsentrasi rendah) dengan nilai $\mathrm{HHI}$ dibawah 1800, dan spektrum II (konsentrasi tinggi) dengan nilai $\mathrm{HHI}$ di atas 1800.

Perhitungan CR4 digunakan untuk mengukur konsentrasi dari empat perusahaan terbesar yang ada dalam satu pasar. Nilai CR berada diantara 0 sampai 100 . Untuk pasar persaingan sempurna, CR sama dengan 0 dan untuk monopoli CR sama dengan 100.

$$
C R_{4}=S i_{1}+. S i_{2}+S i_{3}+S i_{4}
$$

Keterangan/ Remarks:

$C R_{4}=$ Konsentrasi rasio dari 4 perusahaan terbesar dalam satu pasar/ Concentration ratio from 4 largest firms in a industry

$\mathrm{S}_{\mathrm{i}} \quad$ = Pangsa pasar perusahaan (persen)/ Market share of firm (percent)

Rasio konsentrasi berkisar antara nol hingga satu dan biasanya dinyatakan dalam persentase. Nilai konsentrasi yang mendekati angka nol mengindikasikan bahwa sejumlah $\mathrm{n}$ perusahaan memiliki pangsa pasar yang relatif kecil. Sebaliknya, angka rasio konsentrasi yang mendekati satu mengindikasikan tingkat konsentrasi yang relatif tinggi. Di Indonesia Komisi Pengawasan Persaingan Usaha (KKPU) menggunakan nilai CR4 untuk menggambarkan tipe pasar dan tingkat kompetisi dalam pasar tersebut yang dijelaskan dalam Tabel 1.
Hambatan untuk masuk ke suatu pasar adalah hambatan-hambatan yang timbul dalam kondisi pasar yang mendasar. Salah satu cara yang digunakan untuk melihat hambatan masuk adalah dengan mengukur skala ekonomi yang dilihat melalui output perusahaan yang menguasai pasar. Nilai output ini kemudian dibagi dengan output total industri. Penelitian ini menggunakan perhitungan MES (Minimum Efficiency Scale), sebagai indikator untuk mengukur kemampuan masuknya pendatang baru ke dalam suatu industri yang didekati melalui output perusahaan dengan rumus sebagai berikut (Jaya, 2001):

$$
M E S=\frac{Q r}{Q t} x 100 \%
$$

Keterangan/Remarks:

MES = Skala Efisiensi Minimal/ Minimum Efficiency Scale

Qr = Total output perusahaan terbesar/ Total output biggest firms on industries

Qt = Total output dalam industri/ Total output from whole industries

Analisis kinerja pada industri perikanan dapat dilakukan dengan menggunakan variabel Price Cost Margin (PCM) dan efisiensi internal $\left(\mathrm{X}_{\mathrm{Eff}}\right)$. PCM didefinisikan sebagai persentase keuntungan dari kelebihan penerimaan atas biaya langsung. PCM diperoleh dengan membagi selisih antara nilai tambah dikurangi upah terhadap nilai output. Nilai tambah adalah nilai pengiriman dikurangi material, persediaan dan tempat penyimpanan bahan bakar, tenaga listrik dan kontrak kerja (Jaya, 2001).

$$
P C M=\frac{V A-W}{Q V} x 100 \%
$$

Keterangan/Remarks:

$\mathrm{PCM}=$ Margin Harga dan Biaya/ Price Cost Margin

VA = Nilai Tambah/Value Added

$\mathrm{W}=$ Total upah/ Total Wages

QV = Nilai Output/ Output Value

Tabel 1. Tipe Pasar dan Tingkat Kompetisi Dalam Pasar Berdasarkan Nilai CR4. Table 1. Market Types and Competition Levels in The Market Based on CR4 Value.

\begin{tabular}{clr}
\hline $\begin{array}{c}\text { Tipe Pasarl } \\
\text { Market Types }\end{array}$ & \multicolumn{1}{c}{$\begin{array}{c}\text { Tingkat Kompetisi/ } \\
\text { Competition Levels }\end{array}$} & $\begin{array}{c}\text { Nilai CR4/ } \\
\text { CR4 Value }\end{array}$ \\
\hline 1 & Persaingan rendah/ Low competition & $<25 \%$ \\
2 & Oligopoli rendah/ Low oligopoly & $25-50 \%$ \\
3 & Oligopoli tinggi/ High oligopoly & $50-75 \%$ \\
4 & Oligopoli sangat tinggi/ Very high oligopoly & $75 \%-100 \%$ \\
\hline
\end{tabular}

Sumber: Arianto, 2008/Source:Arianto, 2008 
Efisiensi berarti menghasilkan output yang maksimum dengan menggunakan sejumlah input tertentu. Efisiensi terdiri atas efisiensi internal dan efisiensi pengalokasian. Efisiensi internal menunjukkan kemampuan perusahaan dalam menekan biaya produksi. Efisiensi pengalokasian tercapai jika output berada pada tingkat marginal cost (MC) sama dengan harga $(P)$. Semakin efisien suatu perusahaan maka semakin besar keuntungan yang akan diperoleh (Jaya, 2001).

$$
X_{E f f}=\frac{V A}{I V} x 100 \%
$$

Keterangan/Remarks:

Xeff = Nilai Efisiensi Internal/ Efficiency Internal Value

$V A=$ Nilai Tambah Industri/ Industri Value Added

IV = NIlai Input/ Input Value

Analisis perilaku pasar dianalisis secara kualitatif dengan melihat strategi harga, strategi produk dan strategi promosi yang dilakukan pelaku usaha di industri tuna Indonesia.

\section{HASIL DAN PEMBAHASAN}

\section{Gambaran Umum Industri Tuna Indonesia}

Tuna merupakan komoditi ekspor andalan utama dari sektor perikanan nasional karena banyaknya permintaan di pasar dunia sehingga industri perikanan tuna nasional semakin berkembang. Jika diuraikan berdasarkan komoditas ekspor maka terdapat tiga jenis komoditas tuna yang terdapat dalam industri tuna Indonesia yakni produk tuna segar (fresh tuna), produk tuna yang dibekukan (frozen tuna) dan juga ikan tuna olahan diantaranya bentuk tuna kaleng. Analisis data BKIPM, KKP menunjukkan gambaran ekspor tuna berdasarkan jenis komoditas dapat dilihat pada Tabel 2.
Tabel 2 menjelaskan bahwa volume ekspor tuna secara umum mengalami peningkatan sebesar $25,42 \%$ dari tahun 2016 ke 2017 , selain itu diketahui pula bahwa tuna beku merupakan jenis komooditas tuna yang paling banyak diekspor dari Indonesia yang diikuti tuna olahan dan paling sedikit adalah tuna segar. Harga rata-rata tuna segar paling tinggi dibandingkan komoditas tuna lainnya namun volume ekspor ikan tuna segar paling rendah dan mengalami penurunan sebesar $19.09 \%$ dari tahun 2016 ke tahun 2017. Harga ikan tuna segar paling tinggi karena kualitasnya dianggap lebih baik dibandingkan ikan beku dan olahan, akan tetapi volume ekspornya relatif kecil dan menurun karena sebagian besar produksi tuna Indonesia belum memenuhi syarat kualitas tuna segar yang layak ekspor. Selain itu informasi dari para pelaku usaha kualitas ikan tuna Indonesia semakin menurun dipengaruhi oleh kebijakan pelarangan kapal angkut ikan (transhipment) yang dikeluarkan oleh KKP melalui Permen KP nomor 57 Tahun 2014 dalam upaya memerangi Illegal, Unreported dan Unregulated (IUU) Fishing. Kebijakan ini berimbas kepada kualitas ikan tuna yang didaratkan, karena dengan dilarangnya melakukan pemindahan hasil tangkapan dari kapal penangkap ikan ke kapal pengangkut ikan menyebabkan diperlukan waktu yang lebih lama bagi kapal untuk dapat menjual hasil tangkapannya. Sebelum diberlakukan kebijakan ini kapal ikan tuna longline banyak melakukan pemindahan muatan ikan antar-kapal penangkap tuna long line dengan saling menitipkan ikan dari daerah tangkapan ikan ke pelabuhan. Transshipment dinilai dapat mempersingkat waktu pendaratan ikan tuna sehingga kualitasnya dapat lebih terjaga, selain itu dapat menghemat biaya operasional dibandingkan harus mendaratkan kapal terlebih dahulu ke pelabuhan. Hal ini juga disebutkan dalam penelitian Hudayana \& Utami (2017) yang menyebutkan bahwa dengan adanya

Tabel 2. Ekspor Tuna Berdasarkan Komoditas.

Table 2. Tuna Export by Commodity.

\begin{tabular}{lcccc}
\hline \multirow{2}{*}{ Komoditas/ Commodity } & \multicolumn{2}{c}{ Volume $(\mathbf{k g}) /$ Volume $(\mathbf{K g})$} & \multicolumn{2}{c}{ Harga $(\mathbf{R p} / \mathbf{k g}) /$ Price $(\mathbf{R p} / \mathbf{K g})$} \\
\cline { 2 - 5 } & $\mathbf{2 0 1 6}$ & $\mathbf{2 0 1 7}$ & $\mathbf{2 0 1 6}$ & $\mathbf{2 0 1 7}$ \\
\hline Tuna segar/ Fresh tuna & $13,023,879$ & $10,537,860.83$ & 75,169 & 90,303 \\
Tuna beku/ Frozen tuna & $42,798,409$ & $54,752,352.79$ & 60,915 & 83,092 \\
Tuna olahan/ Processed tuna & $23,759,267$ & $34,519,740.53$ & 64,937 & 62,017 \\
\hline \multicolumn{1}{c}{ Jumlah/Total } & $\mathbf{7 9 , 5 8 1 , 5 5 5}$ & $\mathbf{9 9 , 8 0 9 , 9 5 4 . 1 5}$ & $\mathbf{6 7 , 0 0 7}$ & $\mathbf{7 8 , 4 7 0}$ \\
\hline
\end{tabular}

Sumber: Data Operasional BKIPM, 2018 (diolah)/ Source: BKIPM Operational Data, 2018 (Processed) 
kebijakan pelarangan transshipment kapal maka tuntutan kesegaran produk tidak mampu dipenuhi oleh pelaku usaha kapal rawai tuna karena rentang waktu maksimal untuk memenuhi klasifikasi tuna segar layak ekspor adalah antara 8 jam sampai 2 minggu sehingga jika melewati waktu tersebut maka hasil tangkapan harus dibekukan yang akan mengurangi nilai jual. Oleh karena itu hal tersebut menyebabkan volume ekspor tuna segar menjadi lebih rendah dibandingkan komoditas lainnya.

Tingginya volume ekspor ikan tuna beku mencerminkan bahwa industri pembekuan ikan masih menjadi primadona sektor usaha perikanan di Indonesia. Namun yang harus menjadi perhatian bagi seluruh stakeholders adalah harus dilakukan berbagai upaya dalam meningkatkan daya saing terutama untuk ikan tuna beku Indonesia. Penelitian yang dilakukan oleh Cahya (2010) menunjukkan bahwa daya saing ikan tuna beku dan ikan olahan Indonesia lebih rendah dibandingkan ikan tuna segar di pasar Internasional, selain itu penelitian dari Lestari, Syarie \& Sumantadinata (2013) menunjukkan bahwa berdasarkan nilai RCA maka tuna olahan Indonesia mempunyai daya saing lebih tinggi bila dibandingkan dengan tuna beku, namun lebih rendah bila dibandingkan dengan tuna segar. Hal ini diperkuat oleh penelitian Hidayati (2014) yang menyebutkan bahwa daya saing tuna segar dan olahan lebih mapan dibandingkan tuna beku yang berfluktuasi. Posisi daya saing tuna segar, beku dan olahan dalam tahap pertumbuhan ke kematangan. Kondisi ekspor tuna Indonesia menunjukkan hal menarik dimana tuna beku Indonesia memiliki daya saing yang paling rendah namun persentase ekspor paling tinggi dibandingkan ikan tuna segar dan olahan.
Oleh karena itu menjadi keharusan bagi Indonesia untuk meningkatkan daya saing ikan terutama pada tuna beku sebagai komoditas ekspor terbesar, salah satunya dengan meningkatkan mutu dan diferensiasi produk tuna beku sehingga memiliki nilai tambah yang lebih tinggi dan harapannya dapat menambah devisa negara dan kesejahteraan masyarakat.

Ekspor tuna juga dapat dianalisis berdasarkan negara tujuan ekspor. Seperti diketahui dari berbagai literatur (Cahya, 2010; Lestari et al., 2013; Hidayati, Dwidjodono, Masyhuri \& Kamiso, 2015; Yusuf, Arthatiani \& Putri, 2017) menunjukkan bahwa pasar utama tuna ekspor Indonesia adalah Jepang, USA dan Uni Eropa. Dalam penelitian ini menggunakan data ekspor dari BKIPM KKP tahun 2016 dan tahun 2017 menunjukkan sebaran ekspor tuna berdasarkan negara tujuan dapat dilihat pada Gambar 2.

Berdasarkan Gambar 2 tersebut maka dapat diketahui bahwa USA dan Jepang merupakan pasar ekspor utama tuna Indonesia. Thailand menduduki peringkat ketiga sebagai negara tujuan ekspor tuna. USA merupakan negara tujuan ekspor utama yang diduga disebabkan harga tuna di USA relatif lebih tinggi dibandingkan negara lainnya Hal ini menjadi pertimbangan utama eksportir karena tingkat harga yang lebih tinggi sehingga meskipun syarat ekspornya lebih ketat namun USA tetap merupakan pasar utama tuna Indonesia. Sedangkan kondisi ekspor tuna Indonesia di pasar Jepang memiliki fenomena yang berbeda dimana pada tahun 2016 ke tahun 2017 terjadi peningkatan volume ekspor sebesar 33,5\%. Hal ini kemungkinan disebabkan adanya kesepakatan Indonesia-Japan Economic

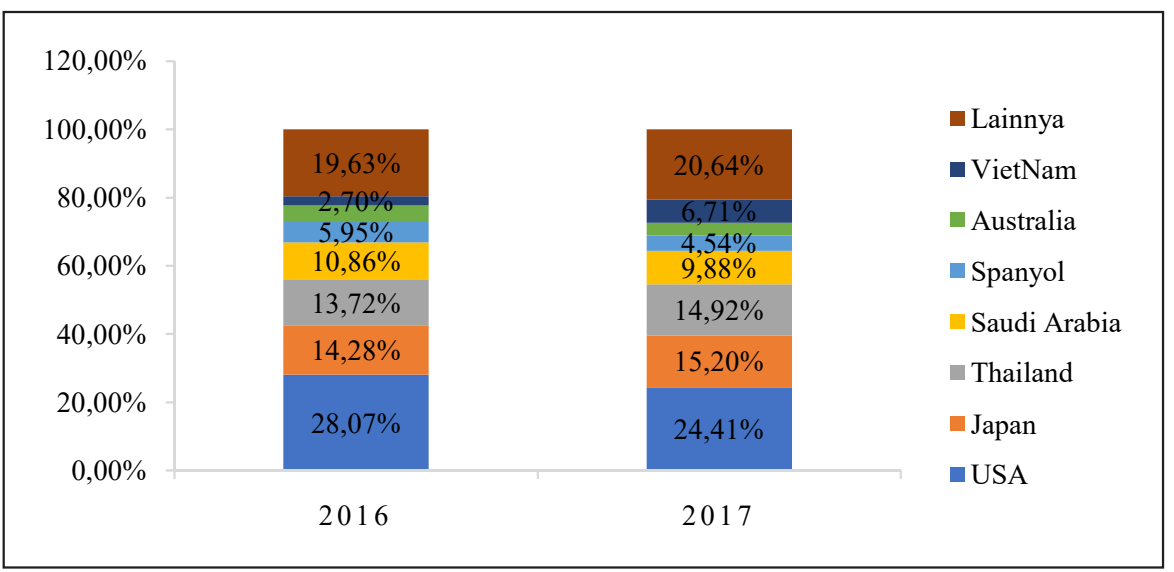

Gambar 2. Sebaran Ekspor Tuna Berdasarkan Negara Tujuan tahun 2016-2017.

Figure 2. Distribution of Tuna Exports by Destination Country of 2016-2107.

Sumber: Data Operasional BKIPM ,2018 (diolah)/ Source: BKIPM Operational Data, 2018 (Processed) 
Partnership Agreement (IJEPA) yang memberikan kepastian akses pasar yang lebih besar bagi produk perikanan Indonesia ke Jepang. Meskipun tarif bea masuk impor masih dikenakan terhadap produk tuna Indonesia namun besaranya semakin menurun dibandingkan tahun sebelumnya. Menurut penelitian Winanti (2011) tarif impor merupakan faktor yang mempengaruhi secara negatif dan signifikan terhadap ekspor tuna di pasar Jepang sehingga dengan adanya kesepakatan ini diduga mendorong peningkatan ekspor tuna Indonesia ke Jepang.

Hal lain yang perlu menjadi perhatian adalah, Thailand merupakan salah satu pasar tujuan utama ekspor Tuna Indonesia, meskipun jika dilihat pada tataran eksportir utama tuna di dunia maka Indonesia dan Thailand merupakan kompetitor sebagai eksportir utama tuna dunia (Hidayati, Dwidjono, Mayhuri \& Kamiso, 2015). Industrialisasi ikan tuna kaleng di Thailand berkembang cukup pesat dan jauh lebih besar kapasitas produksinya dibandingkan Indonesia. Hutagalung (2014) menyebutkan bahwa Thailand memproduksi 55 juta karton ikan tuna kaleng sementara Indonesia hanya memproduksi 8,2 juta karton ikan tuna kaleng. Sehingga dapat disimpulkan Thailand menjadi importir tuna asal Indonesia sebagai bahan baku untuk industri pengalengan tuna dalam negeri. Hal yang sama juga terjadi dengan adanya peningkatan ekspor yang cukup signifikan ke Vietnam sebesar $212 \%$ dan ke Filipina sebesar $359 \%$ yang digunakan sebagai bahan baku industri tuna olahan di Vietnam dan Filipina. Peningkatan ekspor tuna ke Thailand, Vietnam, dan Filipina sebagai kompetitior tuna Indonesia di dunia harus dicermati Pemerintah dan pelaku usaha karena seharusnya potensi bahan baku tuna yang dimiliki Indonesia dapat dioptimalkan untuk mendukung industri pengalengan tuna dalam negeri.

Pemerintah dapat melakukan berbagai intervensi kebijakan untuk membatasi ekspor tuna ke negara kompetitor tuna untuk menjawab kebutuhan bahan baku industri tuna olahan dalam negeri akan tetapi hal ini juga harus dibarengi dengan peningkatan daya saing tuna olahan dalam negeri. Industri tuna dalam negeri harus ditingkatkan kapasitas dan jaminan keamanan pangannya sehingga memiliki keunggulan komparatif jika dibandingkan produk dari negara lainnya sehingga dapat memberikan nilai tambah yang lebih tinggi dan bermanfaat bagi kesejahteraan Indonesia. Dalam upaya membangun industri tuna dalam negeri Pemerintah Indonesia juga harus meningkatkan kemampuan negosiasi internasional untuk dapat menekan hambatanhambatan perdagangan yang dapat menurunkan daya saing tuna Indonesia. Sebagai contoh pengenaan tarif bea masuk tuna Indonesia di pasar Jepang masih dikenakan tarif sedangkan Thailand nol persen hal ini yang menyebabkan tuna Indonesia memiliki harga lebih tinggi di pasar Jepang yang dapat menurunkan ekpor tuna Indonesia. Oleh karena itu kemampuan lobi dan negosisasi atase perdagangan Indonesia menjadi penting untuk menurunkan hambatan-hambatan perdagangan yang dapat mengganggu kinerja ekspor tuna Indonesia.

\section{Struktur Pasar Industri Tuna Indonesia}

Analisis struktur pasar bertujuan untuk mengidentifikasi tingkat persaingan yang terjadi dalam pasar tuna Indonesia. Identifikasi dilakukan menggunakan analisis konsentrasi pasar dan hambatan masuk pasar. Struktur pasar menggambarkan persaingan dalam pasar untuk sebuah produk atau jasa. Di samping itu struktur pasar dapat memberikan gambaran tingkat kekuatan monopoli yang dapat berdampak pada kemampuan daya saing produk perikanan Indonesia.

\section{Analisis Konsentrasi Pasar Komoditas Tuna}

Tingkat konsentrasi pasar dapat dinilai dari besaran pangsa pasar empat perusahaan terbesar (CR4) dan Herfindahl-Hirschman Index $(\mathrm{HHI})$ yang secara empiris sering digunakan dalam mengukur tingkat konsentrasi pasar (Abubakar, Hakim \& Asmarantaka, 2016; Ginoga, 2017; Rekarti \& Nurhayati, 2016). Perhitungan nilai CR4 dan $\mathrm{HHI}$ index dalam industri tuna berdasarkan jenis komoditasnya dapat dilihat pada Tabel 3.

Hasil analisis konsentrasi pasar yang digambarkan dalam Tabel 3 menunjukkan bahwa untuk komoditas tuna olahan berdasarkan rata-rata nilai HHI yakni 2908 memiliki struktur pasar cenderung monopoli, sedangkan berdasarkan rata-rata nilai CR4 sebesar $82.26 \%$ struktur pasarnya termasuk kategori oligopoli sangat ketat. Hal ini menunjukkan bahwa struktur pasar tuna olahan memiliki tingkat konsentrasi tinggi. Konsentrasi pasar merupakan indikator dari struktur pasar yang menentukan perilaku, kinerja, dan tingkat persaingan dalam pasar. Semakin tinggi tingkat konsentrasi pasar, maka semakin besar kekuatan pasarnya yang akan berimbas kepada bentuk pasar persaingan tidak sempurna. 
Tabel 3. Rasio Konsentrasi Pasar Tuna Indonesia.

Table 3. Indonesian Tuna Market Concentration Ratio.

\begin{tabular}{lccccccccc}
\hline & $\begin{array}{c}\text { Jumlah } \\
\text { Komoditas/ } \\
\text { Commodity }\end{array}$ & $\begin{array}{c}\text { Eksportirl } \\
\text { Number of } \\
\text { Exporters }\end{array}$ & \multicolumn{4}{c}{$\begin{array}{c}\text { Herfindahl-Hirschman } \\
\text { Index (HHI) }\end{array}$} & \multicolumn{3}{c}{$\begin{array}{c}\text { Concentration } \\
\text { Ratio (CR4) }\end{array}$} \\
\cline { 2 - 10 } & $\mathbf{2 0 1 6}$ & $\mathbf{2 0 1 7}$ & $\mathbf{2 0 1 6}$ & $\mathbf{2 0 1 7}$ & $\begin{array}{c}\text { Rata-Rata/ } \\
\text { Average }\end{array}$ & $\mathbf{2 0 1 6}$ & $\mathbf{2 0 1 7}$ & $\begin{array}{c}\text { Rata-Rata/ } \\
\text { Average }\end{array}$ \\
\hline $\begin{array}{l}\text { Tuna segar/ } \\
\text { Fresh tuna }\end{array}$ & 87 & 70 & 972 & 927 & 927 & $51.41 \%$ & $50.06 \%$ & $50.74 \%$ \\
$\begin{array}{l}\text { Tuna beku/ } \\
\text { Frozen tuna }\end{array}$ & 128 & 122 & 545 & 904 & 725 & $37.53 \%$ & $43.39 \%$ & $40.46 \%$ \\
$\begin{array}{l}\text { Tuna olahan/ } \\
\text { Processed tuna }\end{array}$ & 21 & 26 & 3425 & 2391 & 2908 & $87.41 \%$ & $77.10 \%$ & $82.26 \%$ \\
\hline
\end{tabular}

Sumber: Data Operasional BKIPM ,2018 (diolah)/ Source: BKIPM Operational Data, 2018 (Processed)

Jumlah eksportir tuna olahan di Indonesia juga memiliki jumlah jauh lebih sedikit dibandingkan dengan eksportir tuna beku dan segar. Hal ini bisa dipahami karena nilai investasi dari teknologi produksi yang diperlukan untuk industri tuna olahan relatif tinggi. Sedangkan untuk ikan tuna beku memiliki rata-rata nilai $\mathrm{HHI}$ sebesar 725 dan CR4 sebesar $40,46 \%$ artinya tingkat konsentrasi pasarmya cenderung oligopoli rendah yang juga terlihat dari jumlah eksportir yang lebih banyak dibandingkan komoditas lainnya.

Berdasarkan penjelasan sebelumnya juga diketahui bahwa volume ekspor tuna beku merupakan yang paling tinggi di Indonesia yang didukung dengan jumlah eksportir yang lebih banyak. Ikan tuna segar memiliki rata-rata nilai HHI sebesar 927 dan CR4 sebesar $50,74 \%$ artinya struktur pasarnya adalah oligopoli tinggi. Oleh karena itu dapat disimpulkan bahwa pasar tuna olahan memiliki tingkat persaingan yang paling tinggi dan cenderung monopoli dengan adanya perusahaan yang dominan mempengaruhi pasar jika dibandingkan kondisi pasar tuna segar memiliki persaingan yang lebih rendah meskipun masih bersifat oligopoli tinggi sedangkan pasar tuna beku memiliki persaingan paling rendah dengan sifat oligopoli rendah.

\section{Analisis Hambatan Masuk Industri}

Hambatan masuk pasar juga dapat digunakan sebagai instrumen untuk menganalisis struktur industri. Jumlah produsen yang keluar masuk pasar akan mempengaruhi produsen sudah ada sebelumnya. Pada praktiknya seringkali ditemukan perusahaan baru sulit untuk masuk dan bertahan didalam pasar karena terhalang oleh kekuatan perusahaan lama yang memiliki modal, skala usaha dan pangsa pasar yang besar. Salah satu indikator yang dapat digunakan untuk mengukur hambatan pasar adalah nilai Minimum Efficiency Scale (MES) yang diperoleh dari nilai output perusahaan terbesar dibagi dengan total nilai output didalam industri yang sama. Nilai MES pada industri tuna Indonesia berdasarkan jenis komoditasnya ditampilkan pada Tabel 4.

Tabel 4 Nilai MES Menurut Jenis Tuna Tahun 2016-2017.

Table 4 MES Value by Tuna Commodity 2016-2017.

\begin{tabular}{lcccccc}
\hline Komoditas/Commodity & \multicolumn{2}{c}{$\begin{array}{c}\text { Jumlah Eksportirl } \\
\text { Number of Exporters }\end{array}$} & \multicolumn{2}{c}{ Minimum Efficiency Scale (MES) } \\
& $\mathbf{2 0 1 6}$ & $\mathbf{2 0 1 7}$ & $\mathbf{2 0 1 6}$ & $\mathbf{2 0 1 7}$ & $\begin{array}{c}\text { Rata-Rata/ } \\
\text { Averages }\end{array}$ \\
\hline Tuna segar/ Fresh tuna & 87 & 70 & $22.04 \%$ & $22.28 \%$ & $22.16 \%$ \\
Tuna beku/ Frozen tuna & 128 & 122 & $16.76 \%$ & $30.07 \%$ & $23.42 \%$ \\
Tuna olahan/ Processed tuna & 21 & 26 & $53.84 \%$ & $43.71 \%$ & $48.78 \%$ \\
\hline
\end{tabular}

Sumber: Data Operasional BKIPM ,2018 (diolah)/ Source: BKIPM Operational Data, 2018 (Processed) 
Berdasarkan Tabel 4 maka dapat diketahui bahwa seluruh komoditas tuna memiliki hambatan masuk industri yang tinggi dengan nilai MES diatas $10 \%$. Komoditas tuna olahan memiliki hambatan masuk industri yang paling tinggi dengan nilai MES sebesar $48,78 \%$. Artinya perusahaan baru memiliki hambatan tinggi untuk memasuki industri tuna olahan, hal ini juga diperkuat dengan nilai konsentrasi pasar yang tinggi pada industri tuna olahan dengan rasio CR4 sebesar $82,26 \%$ yang menunjukkan tipe pasar tuna olahan adalah oligopoli sangat tinggi. Sedangkan jika dilihat dari rasio MES ikan tuna segar memiliki nilai paling rendah dibandingkan jenis ikan lainnya. Hal ini dapat disebabkan karena ikan tuna segar tidak membutuhkan teknologi tinggi dalam menghasilkan produknya dan hanya bergantung pada kualitas penanganan ikan hasil tangkapan di atas kapal dan pada saat pendaratan sehingga peluang masuk kedalam pasar menjadi lebih mudah. Kendala utama bagi perusahaan baru dibidang tuna beku adalah penguasaaan akses terhadap bahan baku tuna. Ketersediaan bahan baku tuna yang fluktuatif dan sangat bergantung pada musim menyebabkan kendala bahan baku menjadi masalah utama yang dihadapi pelaku usaha. Perusahaan yang sudah lama berdiri di industri ini memiliki jaringan supplier tuna yang memungkinkan menghimpun tuna dari nelayan skala kecil untuk memenuhi kebutuhan produksi. Oleh karena itu perusahaan baru di industri tuna dapat menghadapi risiko terputusnya kontinuitas produksi jika tidak memiliki informasi dan jaringan supplier ikan tuna dari nelayan dan kapal penangkapan.

\section{Perilaku Industri Tuna Indonesia}

Perilaku pasar dalam industri tuna orientasi ekspor di Indonesia dianalisis secara deskriptif untuk memperoleh informasi mengenai perilaku perusahaan dalam industri tuna Indonesia yang dijelaskan melalui strategi harga, strategi produk dan strategi promosi yang dilakukan oleh perusahaan.

\section{Strategi Harga}

Struktur pasar tuna yang bersifat oligopoli baik di dalam negeri maupun di pasar internasional menyebabkan proses penentuan harga ditentukan oleh kekuatan yang lebih besar. Negara tujuan utama ekspor tuna Indonesia adalah Jepang dan Amerika Serikat dimana sebagai pembeli kedua negara tersebut memiliki kekuatan untuk mengatur perdagangan komoditas tuna nasional. Ketatnya peraturan ekspor yang disyaratkan negara tujuan menuntut Indonesia harus mengikuti semua peraturan yang ada untuk melakukan ekspor. Negara tersebut termasuk penguasa pasar yang berhak dalam menetapkan harga ikan, sedangkan sebagai pengikut pasar Indonesia tidak dapat menentukan harga. Berdasarkan hasil analisis yang dilakukan sebelumnya maka dapat diketahui untuk pasar USA harga ikan tuna lebih tinggi dibandingkan pasar lainnya namun harus memenuhi kualitas ekspor tuna dan jaminan keamanan pangan sesuai yang ditetapkan FDA. Sedangkan untuk pasar Jepang harganya relatif berfluktuasi karena penetapan harga melalui sistem lelang. Indonesia sebagai salah satu negara pengekspor tuna terbesar di dunia seharusnya dapat memiliki daya tawar penentuan harga yang tinggi terhadap pasar tujuan, akan tetapi tuna merupakan produk yang relatif mudah untuk disubstitusikan dengan komoditas ikan maupun protein lainnya menyebabkan posisi tawar yang lemah di pasar tujuan. Oleh karena itu peningkatan kualitas tuna dan juga kebijakan negosiasi perdagangan internasional untuk mengurangi hambatan tarif dan non tarif tuna Indonesia sangat penting untuk dapat dilakukan.

Harga tuna sangat bergantung dari jenis komoditas tuna dan spesies tuna yang ditangkap. Pasar Jepang sebagai tujuan utama ekspor tuna Indonesia terkenal dengan kebudayaan gemar makan ikan dan mempercayai bahwa ikan tuna dalam kondisi fresh memiliki gizi yang lebih tinggi dibandingkan ikan frozen. Hasil penelitian Yusra, Hamzah \& Syahnur (2014) menunjukkan bahwa pasar Jepang merupakan pasar yang sangat potensial bagi yellowfin segar asal Indonesia yang sangat dipengaruhi oleh GDP perkapita Jepang, nilai tukar dan juga harga yellowfin segar. Selain itu jenis ikan tuna juga mempengaruhi tingkat harga, tuna dengan jenis bigeye tuna memiliki harga yang lebih tinggi dibandingkan yellowfin, skipjack dan albacore tuna (Pan \& Pooley, 2004).

\section{Strategi Produk}

Nilai ekonomis ikan tuna yang tinggi dan banyaknya permintaan di pasar dunia menjadikan perkembangan industri perikanan tuna nasional demikian pesat, tidak hanya produk tuna yang dibekukan (frozen tuna) dan produk tuna segar (fresh tuna), dan dalam bentuk tuna kaleng (canning tuna) atau olahan lainnya. Tuna segar yang diekspor oleh Indonesia berbentuk loin, whole, block dan cut. Sedangkan untuk tuna beku lebih bervariasi produknya meliputi tuna saku, cube, fillet, loin, poke cube, whole, steak, strip meat, chunks steaks, scarp 
meat, slices dan lain sebagainya yang disesuaikan dengan permintaan buyer di negara tujuan. Ikan tuna olahan didominasi oleh ikan tuna kaleng yang diolah dengan berbagai bahan tambahan seperti minyak dan brine, selain itu ikan tuna diolah dalam bentuk dried smoked.

Berbagai produk tersebut disesuaikan dengan negara tujuan, berdasarkan negara tujuan utama maka dapat diketahui bahwa untuk pasar USA tuna beku merupakan produk yang dominan dengan persentase $64 \%$ disusul dengan tuna olahan $34 \%$ dan tuna segar hanya $2 \%$. Kondisi berbeda terjadi di negara Jepang sebagai negara tujuan utama dimana ekspor tuna Indonesia didominasi oleh tuna segar sebesar $54 \%$, tuna beku $38 \%$ dan tuna olahan $9 \%$, hal ini tentunya berkaitan dengan selera penduduk Jepang yang lebih menyukai ikan segar dibandingkan ikan olahan. Negara tujuan utama lainnya adalah Thailand yang membutuhkan bahan baku ikan tuna untuk industri olahan tuna di Thailand. Komposisi jenis tuna Indonesia yang diekspor ke Thailand terdiri dari 95\% tuna beku, $4 \%$ tuna segar dan $1 \%$ tuna kaleng. Diferensiasi produk juga dapat meningkatkan daya saing tuna Indonesia yang harus dibarengi dengan peningkatan kualitas ikan tuna mulai dari penanganan bahan baku di atas kapal hingga penanganan sebelum ekspor.

\section{Strategi Promosi}

Promosi merupakan salah satu upaya pengenalan produk dan sekaligus sarana untuk membentuk citra produk di hadapan konsumen yang pada gilirannya akan meningkatkan volume penjualan. Promosi melibatkan banyak pihak dan biaya yang cukup tinggi namun itu semua jika dilakukan secara tepat akan mendatangkan keuntungan yang sangat besar. Untuk itu, agar volume ekspor meningkat baik dari segi ragam produk ikan tuna maupun jangkauan segmen konsumen yang luas, maka promosi dagangnya bukan sekedar membujuk konsumen tapi lebih mengarah pada memberi keyakinan akan nilai dan manfaat produk ikan tuna Indonesia. Hal ini perlu mendapatkan dukungan dari atase dagang yang mewakili Indonesia baik di negara-negara yang sudah menjadi tujuan ekspor Indonesia, maupun negara lain yang masih terbuka peluangnya untuk dimasuki oleh pasar ekspor ikan tuna Indonesia. Saudi Arabia, Australia dan Afrika dapat menjadi pasar alternatif bagi Indonesia dalam ekspansi ekspor tuna. Hal ini karena pada pasar USA dan Jepang Indonesia hanya sebagai price taker sehingga diperlukan promosi bagi tuna Indonesia untuk dapat memasuki pasar alternatif yang potensial untuk tuna Indonesia. Strategi promosi selain dilakukan pemerintah Indonesia juga dilakukan pelaku usaha dengan ikut serta melalui pameran-pameran dan juga pengiriman sampel ke beberapa buyer yang potensial.

\section{Kinerja Pasar Industri Tuna Indonesia}

Kinerja pasar menurut Dahl \& Hammond (1977) dalam Abubakar et al. (2016) merupakan keadaan sebagai akibat dari struktur dan perilaku pasar. Analisis kinerja pada industri tuna Indonesia dianalisis menggunakan variabel Price Cost Margin (PCM) dan Efisiensi Internal (Xeff). Perhitungan variabel PCM dan Xeff membutuhkan ketersediaan data biaya input, biaya tenaga kerja dan dan total output perusahaan. Salah satu sumber data yang dapat mengakomodir kebutuhan data tersebut adalah menggunakan data survey Industri Besar Sedang (IBS) tahunan yang dilakukan oleh BPS. Jumlah sampel pada survey IBS secara nasional sebanyak 1.703 perusahaan dan mengacu pada kode KBLI terdapat dua kode lapangan usaha yang dapat mewakili industri tuna Indonesia yakni kode 10213 yakni Industri Pembekuan Ikan yang mewakili industri tuna beku dan kode 10219 yakni Industri Pengolahan dan Pengawetan Lainnya untuk Ikan yang dianggap dapat mewakili Industri Tuna Olahan. Kinerja pasar dari kedua lapangan usaha tersebut dianalisis melalui nilai PCM dan Xeff yang akan dianalisis lebih lanjut dalam bahasan sebagai berikut.

\section{Analisis Price Cost Margin (PCM)}

Keuntungan adalah indikator yang dapat digunakan untuk menganalisis kinerja industri tuna. Namun umumnya data mengenai keuntungan pada tingkat perusahaan tidak dipublikasikan. Mengacu pada hal tersebut, maka perhitungan kuntungan dalam penelitian ini diproksi dengan menggunakan pendekatan Price Cost Margin (PCM). PCM adalah nilai keuntungan yang berasal dari kelebihan penerimaan suatu industri atas biaya produksi (Carlton \& Perloff, 2000). Berdasarkan kode lapangan usaha yang mewakili industri tuna maka perhitungan PCM dijelaskan melalui Tabel 5. Berdasarkan Tabel 5 maka dapat diketahui bahwa ikan tuna beku memiliki nilai PCM yang cenderung fluktuatif dimana pada tahun 2012 memiliki nilai yang paling rendah dan tahun 2014 memiliki nilai yang paling tinggi dengan nilai ratarata selama lima tahun sebesar $23,51 \%$. 
Tabel 5. Nilai PCM Industri Tuna Beku dan Tuna Olahan di Indonesia Tahun 2011-2015.

Table 5. PCM Value for Frozen Tuna and Processed Tuna Industry in Indonesia 2011-2015.

\begin{tabular}{cccc}
\hline No & $\begin{array}{c}\text { Tahun/ } \\
\text { Year }\end{array}$ & $\begin{array}{c}\text { Tuna Beku/ } \\
\text { Frozen Tuna }\end{array}$ & $\begin{array}{c}\text { Tuna Olahan/ } \\
\text { Processed Tuna }\end{array}$ \\
\hline 1. & 2011 & 27.14 & 10.94 \\
2. & 2012 & 13.86 & 16.07 \\
3. & 2013 & 26.43 & 28.53 \\
4. & 2014 & 27.84 & 16.24 \\
5. & 2015 & 22.29 & 9.59 \\
\hline \multicolumn{2}{c}{ Rata-Rata/ } \\
Average & $\mathbf{2 3 . 5 1}$ & $\mathbf{1 6 . 2 8}$ \\
\hline
\end{tabular}

Sumber: BPS, 2018 (diolah)/ Source: BPS, 2018 (Processed)

Artinya industri tuna beku memberikan tingkat penerimaan yang cukup menguntungkan dibandingkan dengan biaya yang dikeluarkan perusahaan. Pada industri tuna olahan kisaran nilai PCM masih menguntungkan dengan nilai tertinggi sebesar $28,53 \%$ pada tahun 2013 dan memiliki nilai terendah pada tahun 2015 sebesar 9,59\%. Ginoga (2017) dalam penelitiannya terhadap industri ikan kaleng tahun 1990-2014 menunjukkan rata-rata nilai PCM sebesar $23,98 \%$ artinya secara umum tingkat keuntungan industri ikan di Indonesia masih menguntungkan. Penurunan nilai PCM sejak tahun 2013 pada tuna olahan dapat disebabkan adanya peningkatan biaya input atau penurunan penerimaan dari output yang dihasilkan. Kondisi ini diduga karena adanya perubahan cuaca sejak akhir tahun 2013 yang menyebabkan gangguan ketersediaan bahan baku ikan bagi industri yang juga berimbas pada industri pengolahan dan pengawetan ikan lainnya (Adisurya dalam kontan 2013).

Ketersediaan bahan baku yang kurang kemungkinan menyebabkan meningkatknya harga beli ikan untuk bahan baku industri ikan olahan sehingga menurunkan rasio keuntungan yang diterima perusahaan. Kebijakan pengelolaan sumberdaya ikan dan peningkatan produksi serta pengawasan tindak pencurian ikan di laut Indonesia perlu untuk dilakukan Pemerintah dalam menjamin ketersediaan bahan baku bagi industri pengolahan ikan. Berdasarkan tabel 5 dapat dijelaskan bahwa industri tuna masih menguntungkan dan tuna beku dengan nilai PCM $23,51 \%$ dan lebih tinggi dari nilai PCM tuna olahan yakni sebesar $16,28 \%$. Sebagai bahan perbandingan kinerja pasar antar berbagai industri di Indonesia dapat dilihat dari nilai PCM yang bervariasi contohnya pada industri pulp dan kertas memiliki nilai PCM 27,76\% (Putra, 2009), industri tepung terigu nilai PCM rata-rata sebesar 10,75\% (Apriande \& Daryanto, 2012) dan industri pakan ternak Indonesia memiliki nilai PCM rata-rata $20,94 \%$ (Septiani \& Alexandi 2014). Uraian di atas menunjukkan industri ikan tuna masih menguntungkan dan potensial untuk dapat ditingkatkan kinerjanya dengan menjamin kontinuitas bahan baku sehingga dapat mengurangi flutktuasi biaya input produksi yang dapat mempengaruhi keuntungan industri.

\section{Analisis Efisiensi Internal (Xeff)}

Efisiensi internal (XEff) adalah variabel lain yang dapat digunakan sebagai indikator pengukur kinerja suatu industri. Nilai efisiensi internal diperoleh dari hasil pembagian nilai tambah dengan biaya input yang dikeluarkan oleh perusahaan. Berdasarkan kode lapangan usaha yang mewakili industri tuna maka perhitungan Xeff dijelaskan melalui Tabel 6:

Tabel 6. Nilai Xeff Industri Tuna Beku dan Tuna Olahan di Indonesia Tahun 2011-2015 (\%).

Table 6. Xeff Value Value for Frozen Tuna and Processed Tuna Industry in Indonesia 2011-2015 (\%).

\begin{tabular}{cccc}
\hline No & $\begin{array}{c}\text { Tahun/ } \\
\text { Year }\end{array}$ & $\begin{array}{c}\text { Tuna Beku/ } \\
\text { Frozen Tuna }\end{array}$ & $\begin{array}{c}\text { Tuna Olahan/ } \\
\text { Processed Tuna }\end{array}$ \\
\hline 1. & 2011 & 51.67 & 9.76 \\
2. & 2012 & 30.98 & 43.92 \\
3. & 2013 & 51.11 & 57.54 \\
4. & 2014 & 47.55 & 27.33 \\
5. & 2015 & 36.30 & 17.73 \\
\hline \multicolumn{3}{c}{ Rata-Rata/ } \\
Average & $\mathbf{4 3 . 5 2}$ & $\mathbf{3 1 . 2 6}$ \\
\hline Sumber: BPS, 2018 (diolah)/ Source: BPS, 2018 (Processed)
\end{tabular}

Sumber: BPS, 2018 (diolah)/ Source: BPS, 2018 (Processed)

Berdasarkan Tabel 6 di atas maka diketahui industri tuna beku dan olahan memiliki nilai efisiensi internal yang berfluktuatif. Semakin tinggi nilai Xeff dapat diartikan perusahaan semakin efisien karena adanya peningkatan nilai tambah atau penurunan biaya input. Oleh karena itu berdasarkan tabel tersebut diatas maka dapat diketahui bahwa industri tuna beku lebih efisien dibandingkan dengan tuna olahan. Pada tuna beku nilai Xeff terendah diperoleh pada tahun 2012 dan efisiensi tertinggi tahun 2011 dengan nilai rata-rata sebesar $43,52 \%$. Ikan tuna olahan memiliki nilai efisiensi internal yang paling tinggi pada tahun 2013 dan terendah pada tahun 2015 dengan 
nilai rata-rata sebesar $31,26 \%$. Industri lainnya memiliki nilai Xeff bervariasi, seperti industri pulp dan kertas memiliki nilai Xeff 56,26\% (Putra, 2009), industri tepung terigu nilai Xeff rata-rata sebesar 12,37\% (Apriande \& Daryanto, 2012) dan industri pakan ternak Indonesia memiliki nilai Xeff rata-rata 32,54\% (Septiani \& Alexandi, 2014). Oleh karena itu berdasarkan hasil perbandingan nilai efisiensi internal pada industri tuna perlu untuk ditingkatkan yang dapat dicapai dengan penghematan biaya input dan peningkatan output dari sisi volume maupun nilai ekspornya.

\section{KESIMPULAN DAN REKOMENDASI KEBIJAKAN}

\section{Kesimpulan}

Hasil analisis menunjukkan bahwa struktur industri tuna Indonesia pada tingkat eksportir tuna dilihar dari rata-rata nilai Herfindahl-Hirschman Index (HHI), Concentration Ratio (CR4) dan rasio Minimum Efficiency Scale (MES) menunjukkan tuna segar dan tuna beku memiliki struktur pasar oligopoli, sedangkan untuk komoditas tuna olahan memiliki struktur pasar oligopoli sangat ketat. Oleh karena itu dapat disimpulkan bahwa tuna olahan memiliki tingkat persaingan pasar yang paling tinggi yang juga dilihat dari indikator hambatan masuk industri yang sangat besar. Ketersediaan bahan baku tuna yang fluktuatif dan sangat tergantung musim menyebabkan kemampuan membentuk jaringan supplier menjadi sangat menentukan kemampuan produksi sehingga menyebabkan struktur pasar tuna cenderung oligopoli.

Perilaku pasar industri tuna dianalisis melalui strategi harga yang menunjukan bahwa perilaku pasar industri penentuan harga tuna dilakukan oleh buyer pada negara tujuan yang diukur berdasarkan jenis komoditasnya. Ikan tuna segar dihargai lebih tinggi dengan label 'premium price' digunakan untuk memenuhi permintaan high-end consumer yang biasanya disetarakan sashimi grade. Kualitas kesegaran ikan harus dapat dipenuhi untuk jenis produk ini dimana jangka waktu penangkapan sampai ke eksportir tidak boleh lebih dari dua minggu. Sedangkan ikan tuna frozen dan olahan memiliki harga yang lebih rendah karena tidak memenuhi kualitas ikan tuna yang dipersyaratkan. Sedangkan dilihat dari sisi strategi produk saat ini para pelaku industri tuna orientasi ekspor sudah melakukan berbagai diferensiasi produk terutama untuk tuna beku untuk memenuhi kebutuhan pasar ekspor, sedangkan strategi promosi yang dilakukan melalui pengiriman sampel dan pameran promosi dalam berbagai ajang pameran perdagangan internasional.

Kinerja pemasaran industri tuna yang dapat dianalisi dalam penelitian ini adalah tuna olahan dan tuna beku, dimana dilihat dari nilai profit cost margin (PCM) maka dapat diketahui bahwa industri tuna masih menguntungkan meskipun lebih tinggi tingkat keuntungan dari industri tuna beku dibandingkan tuna olahan. Efisiensi internal industri tuna beku dan olahan memiliki nilai yang cukup fluktuatif namun masih perlu untuk ditingkatkan terutama pada industri tuna olahan yang memiliki nilai efisiensi internal yang lebih rendah daripada tuna beku yang artinya kurang efisien. Oleh karena itu nilai efisiensi internal juga perlu untuk ditingkatkan untuk meningkatkan kinerja pemasaran industri tuna.

\section{Rekomendasi Kebijakan}

Berdasarkan hasil penelitian maka saran dan rekomendasi kebijakan yang dapat diusulkan adalah perlunya mendorong pemerintah untuk melakukan berbagai kebijakan yang memudahkan investasi terutama pada industri tuna olahan sehingga mampu menggeser ekspor tuna ke Thailand sehingga peluang permintaan tuna dunia dapat dipenuhi oleh industri tuna Indonesia. Hal ini dapat berdampak pada peningkatan devisa negara dari peningkatan nilai tambah ekspor tuna. Disisi lain perlu adanya kebijakan pemerintah untuk melakukan pengawasan usaha pada industri tuna khususnya pada tuna olahan sehingga tidak adanya perilaku industri yang dapat menyebabkan persaingan pasar yang kurang sehat. Persaingan pasar yang kurang sehat ini dapat berupa penguasaan bahan baku ikan tuna oleh perusahaan tertentu yang sudah memiliki jejaring dengan nelayan sehingga dapat merugikan perusahaan tuna lainnya dan nelayan karena minimnya informasi harga. Pemerintah harus dapat memgembangkan sistem informasi dan memperbaiki jaringan transportasi dan logistik untuk dapat mengatasi permasalahan kontinuitas bahan baku. Jika hal tersebut dilakukan diharapkan industri tuna dalam negeri dapat berproduksi optimal sehingga meningkatkan kinerja pemasaran melalui peningkatan profit dan efisiensi industri berupa penghematan biaya input dan peningkatan output. 


\section{UCAPAN TERIMA KASIH}

Terima kasih penulis ucapkan kepada Balai Besar Riset Sosial Ekonomi Kelautan dan Perikanan yang telah memfasilitasi dilaksanakannya penelitian terkait dengan industri tuna dalam negeri. Selain itu penghargaan penulis sampaikan kepada Badan Karantina Ikan dan Pengendalian Mutu Kementerian Kelautan dan Perikanan yang banyak membantu terkait dengan pengadaan data bagi penelitian ini.

\section{PERNYATAAN KONTRIBUSI PENULIS}

Kontributor dalam karya tulis ilmiah adalah Freshty Yulia Arthatiani sebagai kontributor utama sedangkan Estu Sri Luhur, Siti Hajar Suryawati, dan Tikkyrino Kurniawan sebagai kontributor anggota yang sudah disepakati bersamasama untuk diketahui semua pihak yang berkepentingan.

\section{DAFTAR PUSTAKA}

Abubakar I., Hakim, D. B. \& Asmarantaka, R. W. (2016) Struktur Perilaku dan Kinerja Pemasaran Biji Kakao di Kabupaten Parigi Moutong Provinsi Sulawesi Tengah. Forum Agribisnis Institut Pertanian Bogor. 6, 1-20.

Adisurya. (2015). Industri Pengalengan Ikan Kesulitan Bahan Baku. Retrieved from https: //industri. kontan.co.id/news/industri-pengalengan-ikankesulitan-bahan-baku.

Apriande, C. \& Daryanto, A. (2012). Analisis Struktur, Perilaku, Dan Kinerja Industri Tepung Terigu Di Indonesia. Forum Agribisnis (Agribusiness Forum), 2 (2), 107-120. DOI: https://doi. org/10.29244/fagb.2.2.107-120

Arianto, E. (2008). Mengukur Struktur Industri Pasar. Retrieved from https://strategika.wordpress.com/ 2008/08/04/mengukur-strukturindustri/.

Bain, J. S. (1956). Barriers to new competition. Cambridge: Harvard University Press.

Baye, M. (2010). Managerial Economics and Business Strategy. Seventh Edition. Singapore (SG): McGraw-Hill.

BKIPM. (2018). Data Operasional BKIPM Tahun 2016 dan 2017. Kementerian Kelautan dan Perikanan, Badan Karantina Ikan dan Pengawasan Mutu: Jakarta.

BPS. (2018). Statistik Ekspor Impor Tahun 2012-2018. Badan Pusat Statistik. Jakarta.

BPS. (2015). Survey Industri Besar Sedang 2011-2015. Badan Pusat Statistik. Jakarta.
Cahya, I. N. (2010). Analisis Daya Saing Ikan Tuna Indonesia di Pasar Internasional. [Skripsi]. Departemen Agribisnis. Fakultas Ekonomi dan Manajemen. Institut Pertanian Bogor. Bogor.

Carlton, D. W. \& Perloff, J. M. (2000). Modern Industrial Organization, 3rd edition. Massachusetts, USA: Addison Wesley Longman, Inc.

Dahl, D. C \& J. W. Hammond. (1977). Market and Price Analysis: The Agricultural Industries. McGraw. New York.

FAO. (2016). The State of World Fisheries and Aquaculture 2016: Contributing to food security and nutrition for all. Rome. Food and Agricultural Organization of the United Nations, 200p.

FAO. (2018). The State of World Fisheries and Aquaculture 2018 - Meeting the Sustainable Development Goals. Food and Agricultural Organization of the United Nations. Rome.

Ginoga, A. N. (2017). Analisis Struktur Perilaku dan Kinerja Industri Pengolahan Ikan dalam di Indonesia (Periode Tahun 1900-2014) [Tesis]. Sekolah Pascasarjana. Institut Pertanian Bogor. Bogor.

Hidayati, S. (2014). Struktur Pasar dan Keududukan Indonesia pada Perdagangan Tjna Olahan di Pasar Dunia, Jepang dan USA. Agritech, XVI (1), 60-66. doi: https://doi.org/ 10.30595/ agritech.v16i1.1019.

Hidayati, S., Dwidjodono, H. D., Masyhuri \& Kamiso, H.N. (2015). Analysis of Determinant Indonesian Tuna Fish Competitiveness in Japanese Market. International Journal of Agricultural System, 3(2), 169-176.

Hudayana, A. H. \& Utami, T. N. (2017). Analisis Kebijakan Larangan Transhipment (Alih Muat) Tangkapan Perikanan Terhadap Kinerja Usaha Penangkapan Ikan Kapal Longline. Journal of Economic and Social of Fisheries and Marine. 5 (1), 78-89.

Hutagalung. (2014). Tuna Indonesia Diekspor ke Thailand Hingga Jepang Retrieved from https:// finance.detik.com/industri/d-2551153/70-tuna-indonesia-diekspor-ke-thailand-hingga-jepang).

Jaya, W. K. 2001. Ekonomi Industri. Edisi Kedua. Badan Penerbit Fakultas Ekonomi, Universitas Gajah Mada, Yogyakarta.

Juwita, I. (2004). Analisis Ekonomi Industri Semen dan Undang-Undang Persaingan Usaha (Pendekatan Struktur-Perilaku-Kinerja) [skripsi]. Bogor (ID): Institut Pertanian Bogor. Bogor.

Lestari, W., Syarief, R. \& Sumantadinata, K. (2013). Strategi Peningkatan Daya Saing Tuna Olahan Indonesia di Pasar Internasional. Forum Agribisnis, 8(1), 36-44. 
Macfadyen, G. T., Huntington, B., Caillart \& V. Defaux. (2016). Estimate of Global Sales Values from Tuna Fisheries-." 1059-reg/r-01/e. United Kingdom: Poseidon Aquatic Resource Management Itd.

Mcwilliams, A. (1993). Efficiency v. Structure-ConductPerformance: Implications for Strategy Research and Practice. Journal of Management. 19(2): 63-78. DOI: 10.1177/014920639301900105.

Pan, M. \& Pooley, S. (2004). Tuna Price In Relation To Economic Factors And Sea Surface Temperature In Fresh Tuna Market. IIFET 2004 Japan Proceedings.

Poernomo, A., Heruwati, E. S., Irianto, H.E., Pranadji, T. Murniyati \& Astuti, I.R. (2001). Pemberdayaan industri pengolahan ikan di Indonesia: Sebuah perspektif. Analisis Kebijaksanaan Pembangunan Perikanan. Pusat Riset Perikanan Budidaya, BRKP, KKP, 86-95.

Poernomo, A. H. \& Heruwati, E. S. (2011). Industrialisasi Perikanan: Suatu Tantangan untuk Perubahan. Squalen, 6(3), 87-94.

Putra, J. E. (2009). Analisis Struktur Perilaku dan Kinerja Industri Pulp dan Kertas di Indonesia [Skripsi]. Departemen IImu Ekonomi. Fakultas Ekonomi dan Manajemen. Institut Pertanian Bogor. Bogor.

Rekarti, E. \& Nurhayati, M. (2016). Analisis Stucture Conduct Performance (SCP) Jika Terjadi Merger Bank Pembangunan Daerah dan Bank BUMN Persero Nilai Aset dan Nilai Dana. Jurnal IImiah Manajemen dan Bisnis, 2(1), 36-50.

Rhoades, S. A. (1993). The efficiency effects of horizontal bank mergers. Journal of Banking and Finance, 17, 411-422. DOI: https://doi.org/10.1016/03784266(93)90041-B.

Septiani, M. \& Alexandi, M. F. (2014). Struktur Perilaku Kinerja Dalam Persaiangan Industri Pakan Ternak di Indonesia Periode Tahun 1986-2010. Jurnal Manajemen dan Agribisnis, 11(2), 77-88.

Sibagariang, O. P., Fauziyah \& Agustriani, F. (2011). Analisis Potensi Lestari Sumber daya Perikanan Tuna Longline di Kabupaten Cilacap, Jawa Tengah. Maspari, 03(02): 24-29.

Syahrani, D.A, Musadieq M.Al \& Darmawan, A. (2017). Analisis Peran Kebijakan Illegal, Unreported and Unregulated Fishing (IUU) pada Ekspor Ikan Tuna dan Udang Tangkap (Studi pada sebelum dan sesudah penerapan Permen KP nomor 56 dan 57/ PERMEN KP 2014 terhadap Volume Ekspor Tuna dan Udang Tangkap di Jawa Timur). Jurnal Administrasi Bisnis (JAB). 45 (1).

Winanti, A. (2011). Analisis Permintaan Ekspor Ikan Tuna Segar Indonesia di Pasar Internasional. [Tesis]. Sekolah Pascasarjana. Institut Pertanian Bogor. Bogor.
Yusra, M., Hamzah, A \& Syahnur, S. (2014). Analisis Permintaan Tuna Sirip Kuning (Yellowfin) Indonesia di Pasar Jepang. Jurnal IImu Ekonomi Pascasarjana Universitas Syiah Kuala: 2(2): 72-81.

Yusuf, R. Arthatiani, F.Y. \& Putri, H.M. (2017). Peluang Pasar Ekspor Tuna Indonesia: Suatu Pendekatan Analisis Bayesian. Jurnal Kebijakan Sosek Kelautan dan Perikanan. 7 (1): 39-50. DOI: http://dx.doi.org/10.15578/ jksekp.v7i1.5746. 